\title{
社会問題解決策の影響分析手法確立に向けた研究 〜既存不適格住宅耐震性向上問題を事例として
}

A Study towards establishing influence-analysis method for measures against social problems - A case study on social problem of improving earthquake-resistance of existing pre-code-revision houses

\section{古場 裕司 $^{1} \cdot$ 白戶 智 $^{2} \cdot$ 山口 $\quad$ 健太郎 ${ }^{3} \cdot$ 堀井 秀之 $^{4}$}

1 修士 (学術) (株) 三菱総合研究所 社会システム政策研究部 (E-mail:y-koba@mri.co.jp) 2 工学修士 (機械工学・科学政策) (株)三菱総合研究所 社会システム政策研究部 (E-mail:s-shirato@mri.co.jp) 3 工学修士(社会システム政策) (株)三菱総合研究所 社会システム政策研究部 (E-mail:yamaken@mri.co.jp) 4Ph.D. (社会技術) 東京大学大学院教授 工学系研究科社会基盤工学専攻 (E-mail:horii@civil.t.u-tokyo.ac.jp)

社会問題の解決を图る際,立案された解決策を社会に導入した場合の影響をあらかじめ把握することは， 解決策の実現可能性や有効性を評価し,社会への実装に際しての課題を検討するために有効である .また， 解決策の立案から導入までの合意形成を支援したり，複数の解決策の候補を評価するためにも有効に活用 できる.

このような観点から，本研究では社会問題の解決策に関する社会への影響を分析するための手法につい て現実の問題への適用を試みた . 社会問題の解決策の例として, 既存不適格住宅の耐震性向上に関する新 制度の提案を取り上げ，制度導入時に予想される効果と限界を把握した．この結果を踏まえ，社会問題の 解決策に関する影響分析手法の有効性について検証し, 本手法の可能性と今後の課題について示した 。

キーワード : 社会問題の解決策，影響分析手法，複雑問題の解決，意思決定，既存不適格住宅

\section{1.はじめに}

社会問題の解決策を検討する場合に，発想・考案され た解決策について, 実現可能性や有効性, 社会への実装 に際しての課題を検討し, 解決策の改善, あるいは複数 の解決策候補の中から最適なものの選択を行うことか洧 効である ${ }^{1)}$ (Fig.1) .

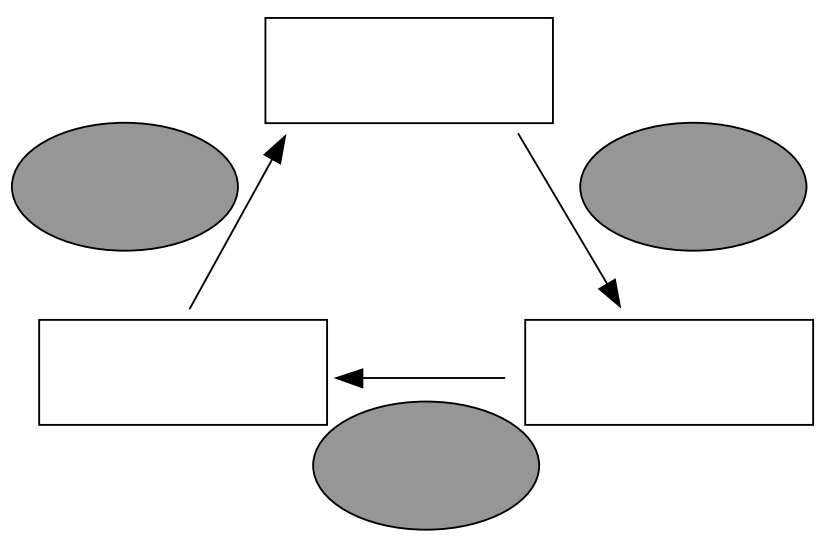

Fig. 1 問題解決策の設計ループ

社会事象への影響を分析 (予測) するための方法論は 多樣な学問領域て検討されており認知心理学 社会学 ,
社会心理学, コミュニケーション論, 政治学, 行政学, 法律学, 経済学など広範な学問領域力関連している。

方法論の視点から見ると，予測のタイプとして投影的 予測, 理論的予測, 直感的予測の 3 つを区別することが

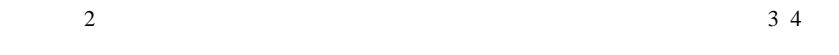

Table. 1 予測の種類と関連領域

\begin{tabular}{|c|c|c|c|}
\hline $\begin{array}{l}\text { 予測の } \\
\text { 種類 }\end{array}$ & 特徵 & 概要 & 関連する学問領域 \\
\hline $\begin{array}{l}\text { 投影的 } \\
\text { 予測 }\end{array}$ & 帰納的 & $\begin{array}{l}\text { 過去から現在にかけての歴 } \\
\text { 史的トレンドを将来に向け } \\
\text { て延長する帰納的予測方 } \\
\text { 法. 通常何らかの形の時系 } \\
\text { 列分析に基づく. }\end{array}$ & $\begin{array}{l}\text { 統計学 (時系列分析, } \\
\text { 最小二乗法, 指数平滑 } \\
\text { 法などの統計的推論) }\end{array}$ \\
\hline $\begin{array}{l}\text { 理論的 } \\
\text { 予測 }\end{array}$ & $\begin{array}{l}\text { 演繹的 } \\
\text { 規範的 }\end{array}$ & $\begin{array}{l}\text { 理論的法則などの明確な前 } \\
\text { 提に基ついだ演繹的予測方 } \\
\text { 法 . システムを記述するモ } \\
\text { デルを構築する. }\end{array}$ & $\begin{array}{l}\text { ゲーム理論, } \mathrm{OR} \text {, 合理 } \\
\text { 的選択理論, シミュレ } \\
\text { ーション }\end{array}$ \\
\hline $\begin{array}{l}\text { 直感的 } \\
\text { 予測 }\end{array}$ & $\begin{array}{l}\text { 主観的 } \\
\text { 遡及的 }\end{array}$ & $\begin{array}{l}\text { 将来についての主観的判断 } \\
\text { に基づく予測方法 . 結侖か } \\
\text { ら遡る遡及的な面がある. }\end{array}$ & $\begin{array}{l}\text { OR (デルファイ法, シ } \\
\text { ナリオライティング , } \\
\text { FATなど) , 未来学 }\end{array}$ \\
\hline
\end{tabular}

政策問題のような構造が複杂隹て解を一意に導き出せな いようなタイプの問題に対する予測は，演繹的・規範的 なアプローチを直接適用することか困難であり，限定的 
な制約条件のもとでのモデル化 (理論的予測) ,デルファ イ法のような主観的方法の活用 (直感的予測), さらに光 れら手法の組み合わせなどの工夫が行われてきた ${ }^{3)}$ 苂 のの，これまで, 複雑な主体や社会制度力関係する社会 問題の解決策を, 複数の専門分野を横断する視点で評 価・分析するための手法は十分検討されてきたとは言え ず, 社会問題解決のための, メタレベルでの方法論か求 められている.

本研究では,このような複杂隹な社会問題の解決策を設 計するための手法の一環として，解決策を導入した場合 の社会の变化を推定するために提案されている「社会問 題の解決策の影響分析手法」 ${ }^{\left.1)^{5}\right)}$ について検討すること を目的とした . 現在問題になっている実際の社会問題を 取り上げ, 社会問題の解決策の影響分析手法を適用して ケーススタディを行い, 手法の有用性と限界について検 討した。

\section{2. 問題解決策の影響分析手法}

本研究て検討した「問題解決策の影響分析手法」は， 社会問題に代表される, 分野横断的な知見の統合が必要 な複杂隹な問題の解決策につい, 弚れを社会へ実装した 場合の影響を検討するための方法論である . 本手法は , (1)シナリオの作成, (2)因果ネットワークの作成, (3)因果 関係の根拠の検討，(4)予測に対する評価とフィードバッ ク ，(5)予測シナリオの確定という5つのステップから構 成される (Fig.2) .

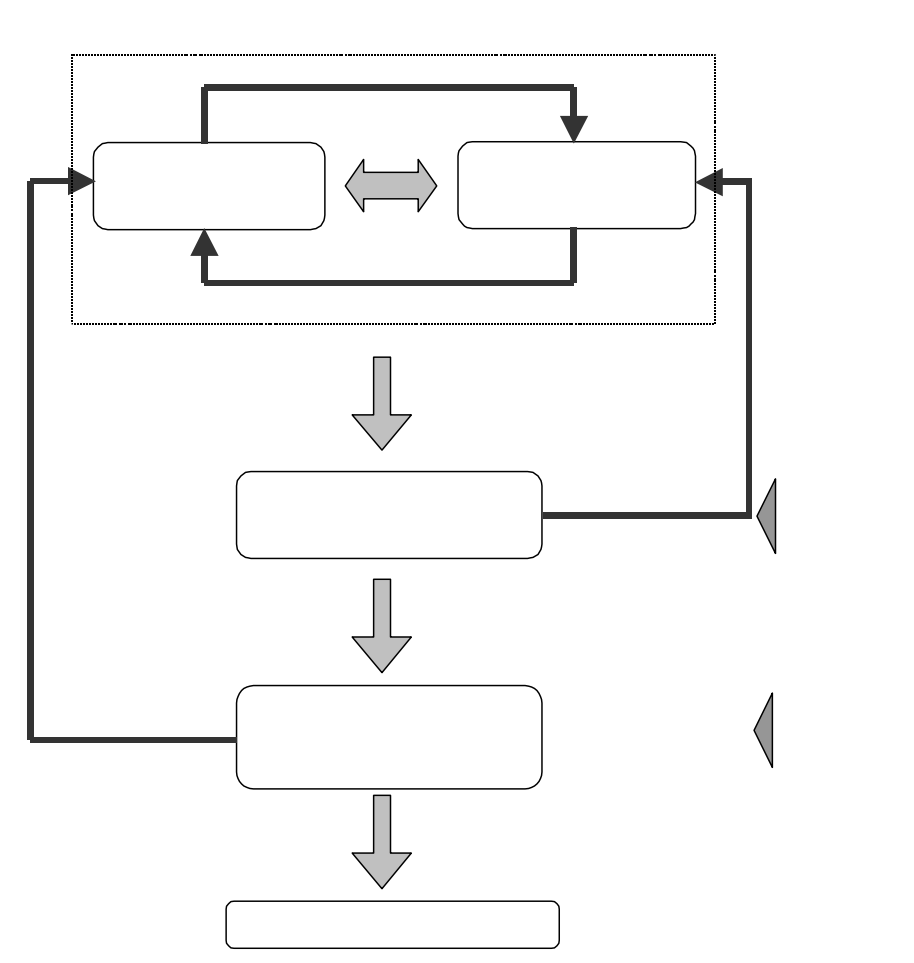

Fig. 2 問題解決策の影響分析のプロセス

\section{(1) シナリオの作成}

問題解決策の導入により将来起こるであろう状況を， 関係する行為主体 (プレーヤー) の行動特性や各種の環 境条件を勘案しながら定性的なストーリーとして記述す る.樣々な可能性を考えた上で, 最も可能性か高いと思 われるものを選択していく .

例えば, 安全や安心に係る社会問題か㳔象であれば， 始めに, 安全・安心を実現するための解決策 (シナリオ のスタート),およひ結果としての安全·安心を評価する ための指標 (シナリオのゴール) を明確にし, 問題解決 策 (スタート) から安全・安心評価指標 (ゴール) へ効 果が波及していく因果関係をシナリオとして記述する .

これはいわゆるシナリオ・ライティング手法を活用し たものである .また ,このシナリオ作成にあたっては KJ 法やブレーンストーミング法なども活用できる .

\section{(2) 因果ネットワークの作成}

(1)て作成したシナリオに基ついて，事象を要素に分解 し，直接的な関係のある要素どうしを矢印でつなき，問 題解決策の影響が波及する樣子を変化の連鎖として図示 する抽象的あるいは直線的な記述になりがちな文章(シ ナリオ) て記述された事象の要素あるいは要素間の関係 を明確にし，事象を視覚化・構造化することがここでの 目的である。

間接的な因果関係は排䣄し, 直接的な因果関係のみを 記述する . 因果関係束存在するかどうかわからないとき には, 矢印は残し次のステップて検証する .

定性的なシナリオを要素にブレークダウンする手法と して,イベントツリ一解析 (ETA) , フォールトツリ一解 析 (FTA), SHELL 分析, 4M4E, 確率論的安全評価法 (PSA) などの手法を用いることができる .

\section{(3) 因果関係の根拠の検証と有望シナリオの抽出}

因果ネットワークて仮定した要素間関係の一つ一つに つて, 既存の調査や研究成果を基に文献資料のシステ マティックレビュー , クロスセクション法などを用いて 因果関係の存在を検証する．可能であれば時系列分析や 回帰分析などを用いて関係性の強度や関数形を推測する。 既存の資料などから関係性力把握できない場合にはデ ルファイ法 , 仮想順序付け法, コンジョイント法, 期待 効用理論，多次元尺度構成法などの手法を用いてデータ を収集したりモデルを構築したりすることも有効である． 検証の結果は一覧にまとめる . 因果関係がみられない と判断された場合は因果ネットワークを修正する . 因果 関係が自明の場合根拠は不要であり, 一方, 根拠力複数 ある場合はすべての根拠を挙げる. 複数の根拠か相反す る場合は，根拠の強さを基準として評価・決定する . 
(4) 予測に対する評価とフィードバック

(1) から (3) までのプロセスにより構築された予測 シナリオおよび因果ネットワークについて , アンケート やヒアリングを通じて得られる外部の専門家, 非専門家 などの評価も活用しながら，产の信頼性を検討する .

\section{(5) 予測シナリオの確定}

評価に基づき修正されたシナリオを，最終的な予測シ ナリオ，因果ネットワークとして確定する .

因果ネットワークに基づき, 最終シナリオとして描い た望ましい社会の状態を害現させる（または望ましくな (社会の状態を回避する) ために特に留意すべき点を明 らかにする。

\section{(6) 本手法の意義・独自性}

上に述べたように，本稿で検討する社会問題解決策の 影響分析手法は，既存の手法を構成要素に含んでいる. しかし，これらの個別の要素手法を明示的に統合するこ とで方法論としての確立を企図している点や，特に社会 問題の解決策導入の影響を事前に分析しようとする試み である点などに，本手法の意義と独自性がある．

\section{3. 既存不適格住宅の耐震性向上策への適用}

\section{1. 既存不適格建築物の耐震改修促進問題の概要}

既存不適格建築物とは, 現在の耐震基準である新耐震 基準か制定された 1981 年以前の住宅のうち新耐震基準 レベルの耐震性能を有していない住宅 (約 1300 万戶) を 指す . 阪神・淡路大震災においても, 新耐震基準以前と 推定される建物の被害が大きかったことが分かっており， 新耐震基淮以前の建物の危険性力指摘されているところ である。

既存不適格住宅の耐震性を確保するには，建て替えと 耐震補強の二通りの方法があるが，耐震補強の方がコス 卜的にも安価であり，早期の耐震性の確保が見込める. 一方で, 国や自治体て耐震補強を促進する施策を講じて いるにもかかわらず，耐震補強の実施はごく一部に限ら れているの力現状である .

このような背景のもと, 本研究ては既存不適格建築物 耐震改修促進問題を取り上げ，社会問題の解決策の影響 分析手法に従い, シナリオの作成, 因果ネットワークの 作成, 文献検索及び仮想的状況下における耐震改修利用 意向に関するアンケート調査による因果関係の検討, 及 び専門家による評価を行い，解決策としての社会技術を 導入した際の効果についての検討を行うとともに , 本手 法の有効性と課題について検討を行った .

\section{2. 問題解決策}

既存不適格住宅の耐震性向上のための制度として , 中
古住宅耐震性価格査定制度, 中古住宅売買/賃貸時説明 責任制度, 生命/損害保険耐震性割引制度について取り 上げた (Table.2). 各制度の概要及び選定の過程について は別稿を参照されたい ${ }^{6}$.これらはいずれも既存の制度 にない新たな制度として考案されたものである．

Tabl e. 2 影響分析の対象として取り上げた既存不適格住宅耐 震性向上のための新制度

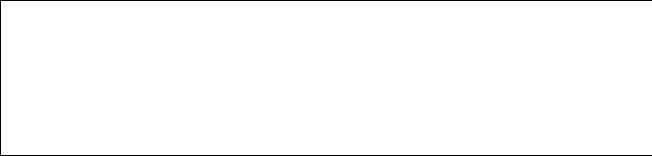

3.3. シナリオ・因果ネットワークの作成

これらの制度について, 導入時の効果に関して想定さ れるスタートとゴールを設定し , スタートとゴールをつ なぐシナリオを作成した (Table.3〜5) .

Table. 3 中古住宅耐震性価格査定制度のシナリオ

\begin{tabular}{|c|}
\hline $\begin{array}{l}\text { シナリオのスタート : } \\
\text { ·不動産鑑定基準における耐震性評価の明確化 } \\
\text { シナリオのゴール : } \\
\text { ·住宅居住者の地震に対する安心の向上 } \\
\text { ·地震発生時の被害の減少 } \\
\text { ·復興時の社会的コストの減少 } \\
\end{array}$ \\
\hline 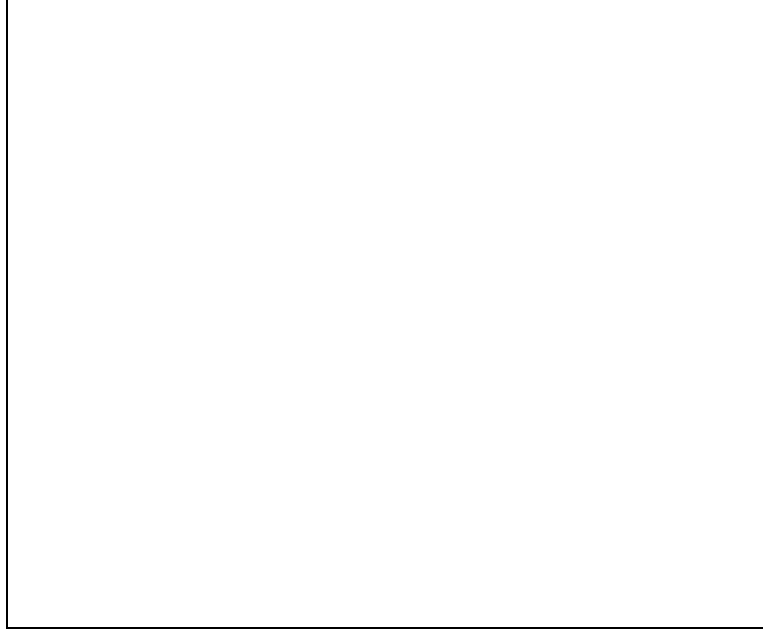 \\
\hline
\end{tabular}

Table. 4 中古住宅売買/賃貸時而震性説明責任制度のシナリオ

\begin{tabular}{|l|}
\hline シナリオのスタート : \\
·中古住宅の売買, 賃貸時の耐震性の説明を義務化 \\
シナリオのゴール : \\
·住宅居住者の地震に対する安心の向上 \\
·地震発生時の被害の減少 \\
·復興時の社会的コストの減少 \\
\hline シナリオ : \\
住宅販売業者に耐震性の買主への説明義務か課せられると, 売 \\
主にあらかじめ耐震性を明らかにしておく (事前に耐震診断を受 \\
\hline
\end{tabular}


ける) 圧力が慟く . 耐震晾断の結果 , 耐震改修工事の必要性を認 識することにつながり，売主の耐震改修の意思決定を促進する． 光の結果, 耐震性の高い註宅力増加し, 居住者の安心の向上, 震 災時の被害の減少, 社会的復興コストの減少につながる。

一方, 耐震改修のコス卜は, 買主のコスト合理性の認識の範囲 て住宅価格に反映され，このことも売主の耐震改修の意思決定を 促進する . ただし , 買主の考えるコスト合理性を大きく越えるよ うな価格差は許容されず，市場において，耐震改修による売主の コスト負担分と買主の考えるコスト合理性とのバランスにより， 住宅の耐震性能に対する適正な価格差力形成される.

また，制度導入時に制度について国民に広くPRすることによ り，国民のリスク認知や耐震診断・改修の必要性の認識，コスト 合理性の認識に影響を与え, 耐震診断や耐震改修の意思決定を促 進する。

Table. 5 生命/損害保険耐震性割引制度のシナリオ

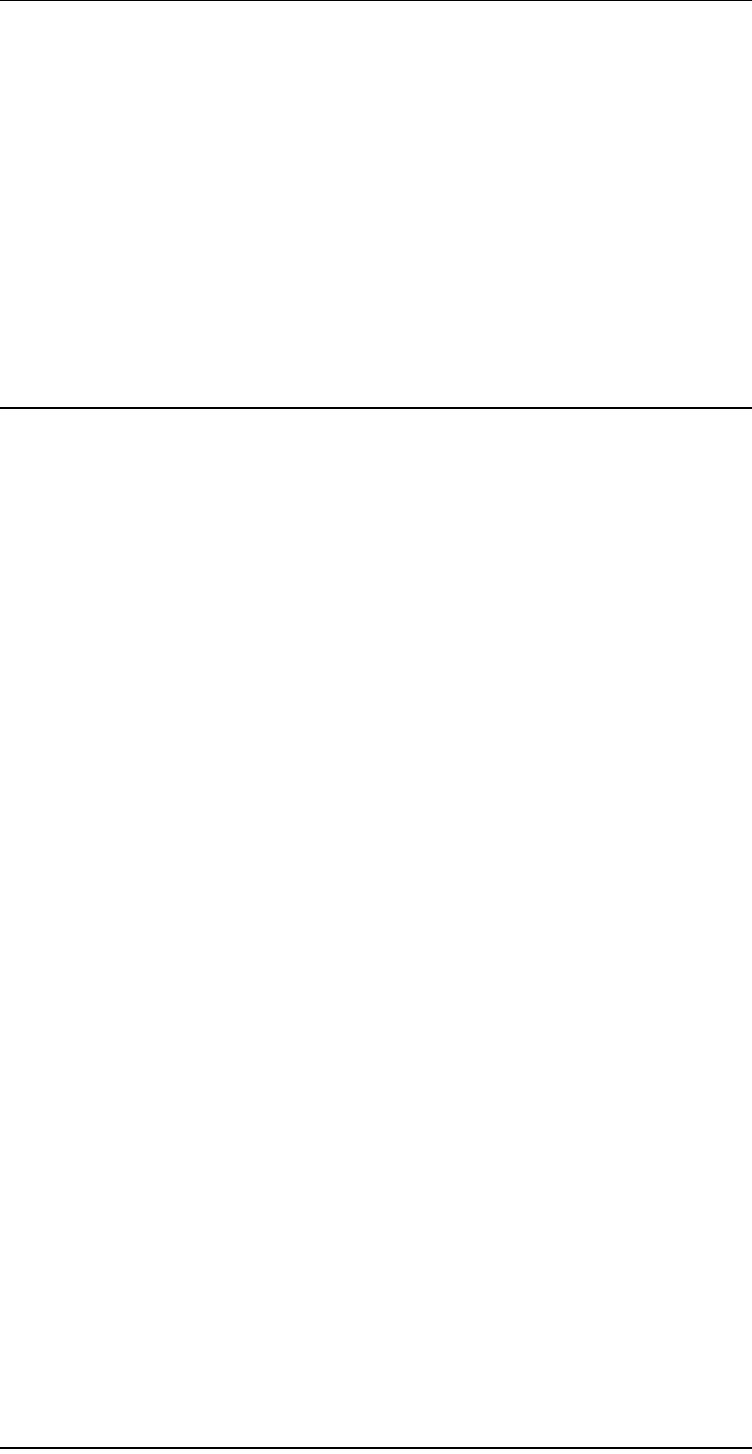

加入のためには, 耐震部断を受けることが必要であり，さらに 耐震診断の結果耐震性が十分でないと分かった場合には，耐震改 修を行う必要があるため, 間接的に加入希望者の耐震言断，耐震 改修の意思決定を促進する .ここでは, 割引される保険料と，耐 震診断・耐震改修のコスト，およひ洏震性を強化した住宅に住む ことによって得られる安心との見合いで, 意思決定がなされるこ とになる . 耐震改修の意思決定が促進された結果 , 耐震性の高い 住宅力増加し，居住者の安心の向上，震災時の被害の減少 , 社会 的復興コストの減少につながる .

間接的には，耐震改修のコストをどこまで売買価格や家賃に上 乗せできるかという問題も関連し，買い手の許容度にも影響を受 けるが, 大きな影響ではないと考えられる .

保険加入〜の意向がこのフローをドライブする要因となってお り，保険加入へのインセンティブ (この場合には保険料の割引) をどの程度与えられるかが重要となる．

また，制度導入時のP R ，生命保険会社，損害保険会社による 新制度のPR（耐震性強化の必要性のP R を含む）などを通じて， リスク認知や耐震言断・改修の必要性の認識, コスト合理性の認 識に影響を与え，耐震診断や耐震改修の意思決定を促進する。

また，「国・自治体」「個人」「住宅メーカー」などのシ ナリオに登場するプレーヤーを洗い出し, シナリオで述 ベられている事象を要素に分解してプレーヤーごとに整 理し, さらに要素間の関係を矢印でつな゙゙ことで, 因果 ネットワークを作成した (Fig. 3〜5) .

シナリオから因果ネットワークを作成する中で当初想 定されなかった新たな要素や要素間の関係性を発見する など, Fig.2 に示すように，(1)シナリオの作成と(2)因果ネ ットワークの作成のプロセスは相互に関係しながら進め られた .

なお，因果ネットワークの構築にあたっては，個人の 意思決定プロセスを,「リスクの認知」 $\rightarrow 「$ 対策の必要性

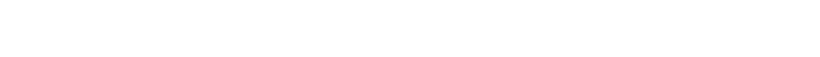
の検討」 $\rightarrow$ 意思決定」と想定しモデル化した (Fig.6) . このモデルを耐震診断の意思決定 耐震補強の意思決定， 生命/損害保険加入の意思決定など個人の意思決定に関 わる場面に統一的に適用するためのテンプレートとして 使用した .

\section{4. 因果関係の検討}

\section{(1) 既存資料による因果関係の検討}

文献検索 ，インターネット検索等により，フロー中の 因果関係の根拠となるデータの収集を行った .

文献検索からは,新耐震基準の住宅と旧耐震基準の住 宅では価格差か形成されること」耐震改修により家主の 収益は増加する可能性があること」住宅の耐震性向上は， 地域の防災性向上に寄与すること (住宅の倒壤のリスク を低下させるだけでなく, 出火の割合の低下や倒壊住宅 による道路の閉塞がないとて避難・消火・救助活動の 円滑化につながる)」「費用負担か洏震改修を受ける際の 障害の一つになっていること」といった因果ネットワー ク中の関係性を根拠づけるデータや「住宅を貨貸してい る場合には借地借家法による賃借人の権利保護力障害と なって改修か実施しにくくなること」といったシナリオ 作成時に考慮されていなかった論点を指摘するデータが 収集された (Table.6) . 
社会技術研究論文集 Vol.2, 112-122, Oct. 2004

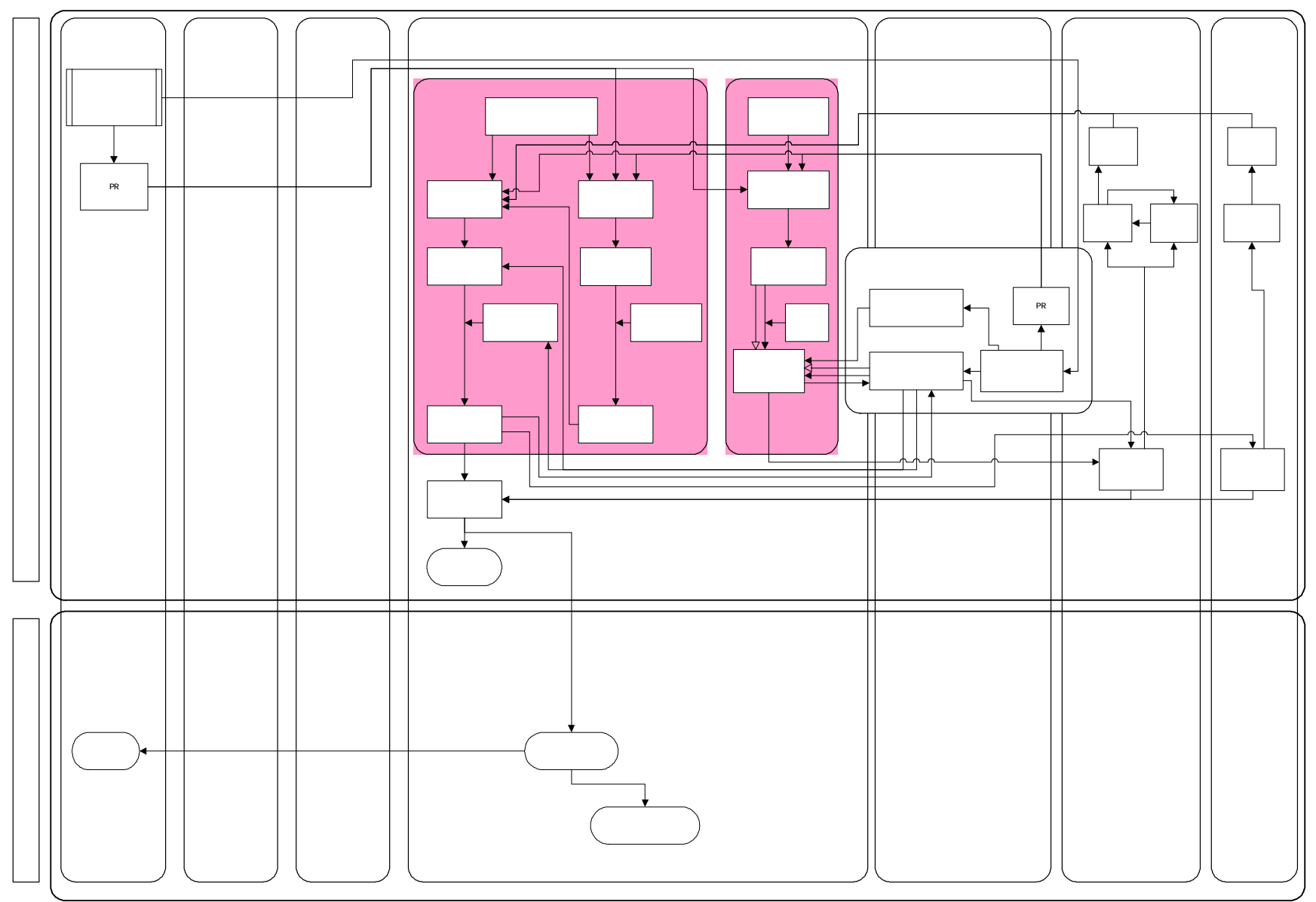

Fig. 3 中古住宅耐震性価格査定制度の因果ネットワーク

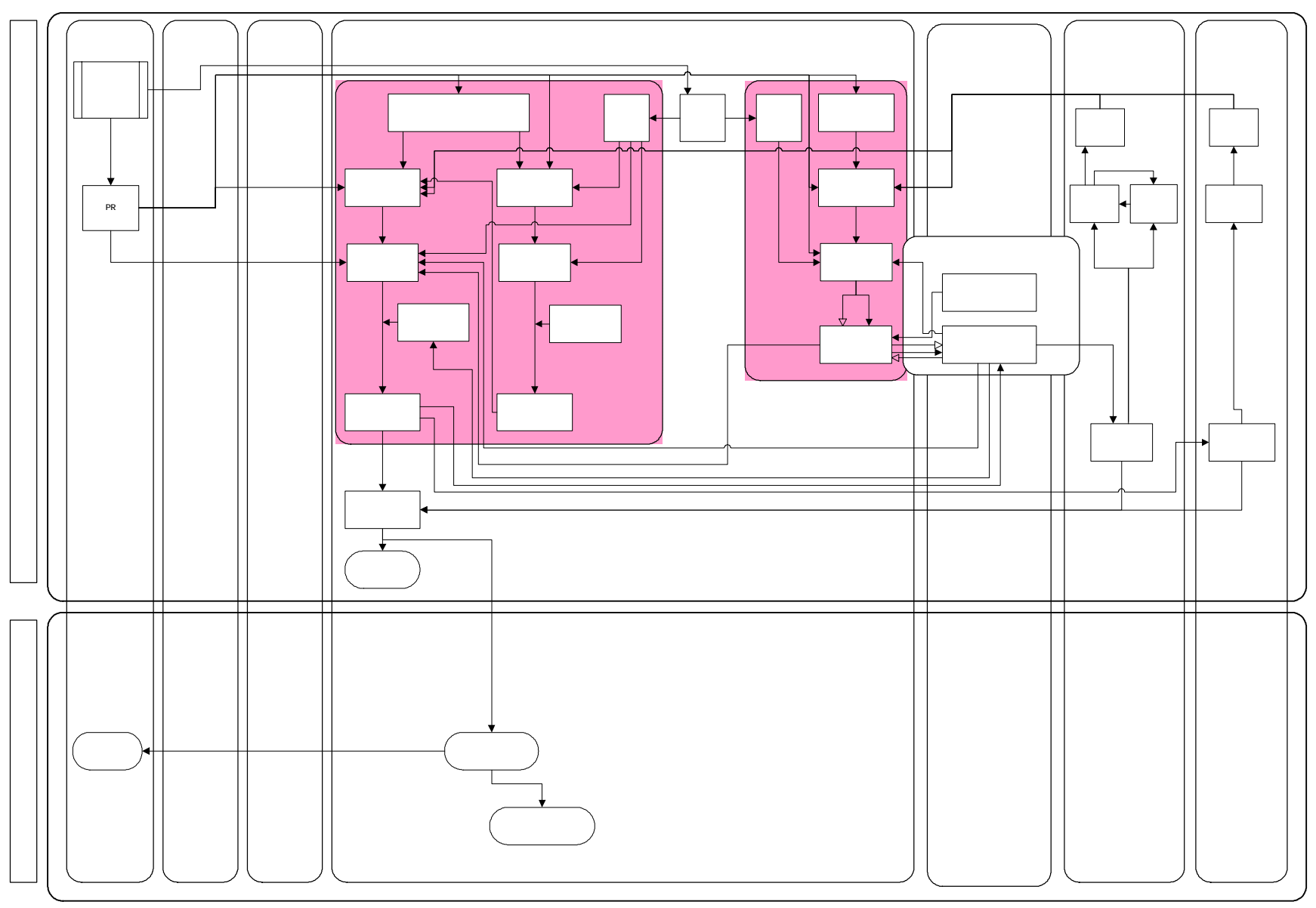

Fig. 4 中古住宅売買/賃貸時耐震性説明責任制度の因果ネットワーク 


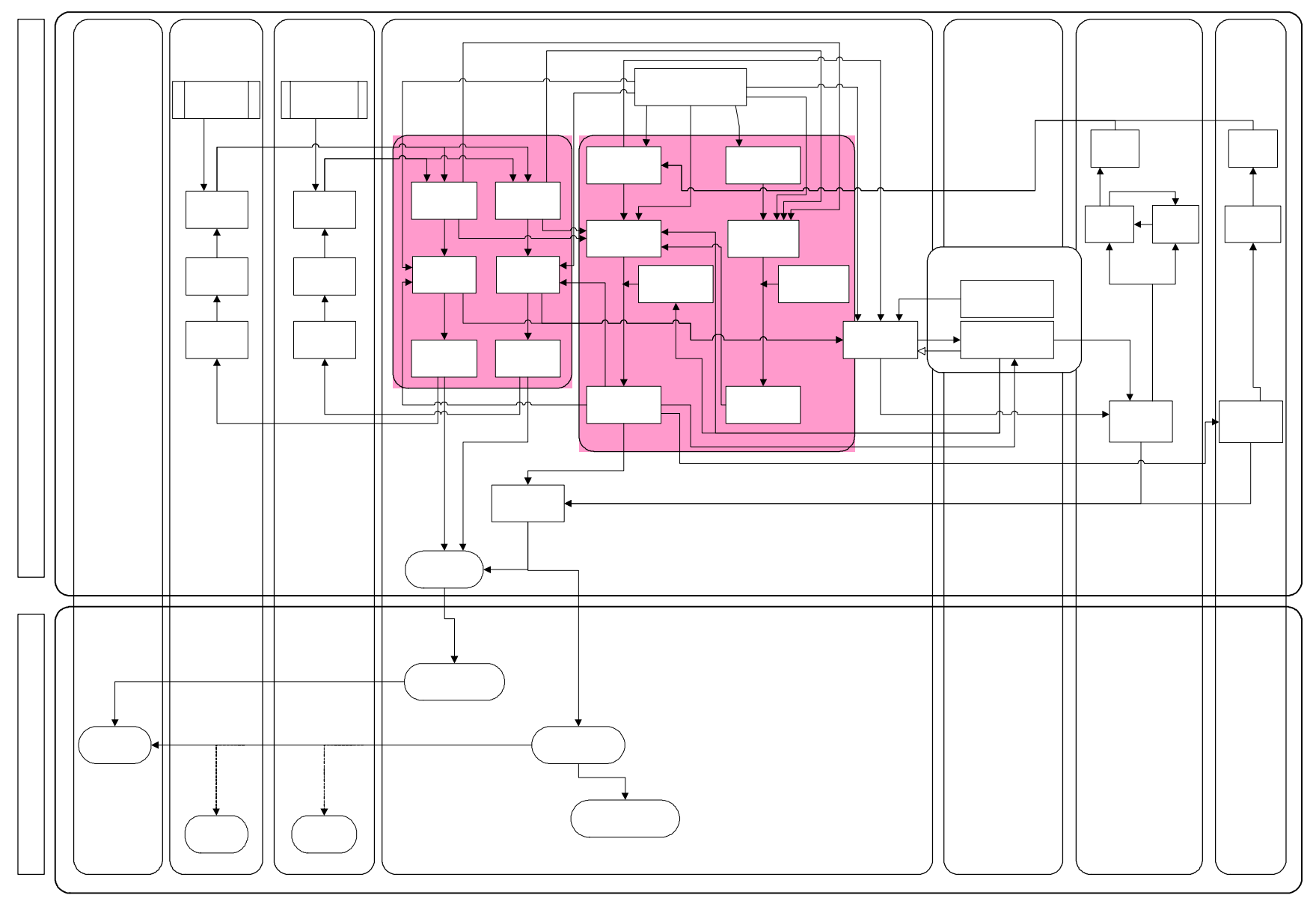

Fig. 5 生命/損害保険耐震性割引制度の因果ネットワーク

Table. 6 既存資料による因果関係の検討結果 (一部)

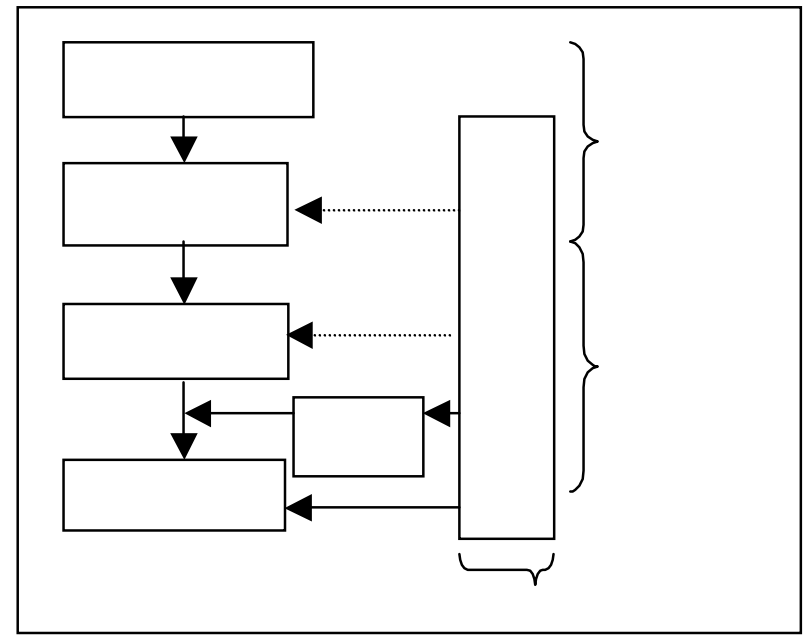

Fig. 6 個人の意思決定モデル

\begin{tabular}{|c|c|c|c|c|}
\hline 原因 & 結果 & $\begin{array}{l}\text { 因 } \\
\text { 果 } \\
\text { 関 } \\
\text { 係 }\end{array}$ & $\begin{array}{l}\text { 根 } \\
\text { 拠 } \\
\text { 強 } \\
\text { 度 }\end{array}$ & 根拠データ \\
\hline $\begin{array}{l}\text { (個人) } \\
\text { 耐 震 性 } \\
\text { の高 い } \\
\text { 住宅 の } \\
\text { 増加 }\end{array}$ & $\begin{array}{l}\text { (個人) } \\
\text { 地震 被 } \\
\text { 害の減 } \\
\text { 少 }\end{array}$ & + & 0 & 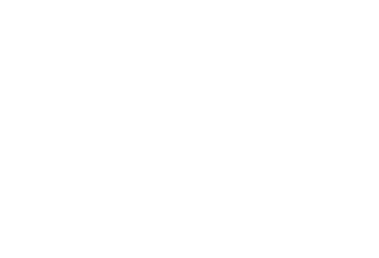 \\
\hline $\begin{array}{l}\text { (個人) } \\
\text { 地震被 } \\
\text { 害の減 } \\
\text { 少 }\end{array}$ & $\begin{array}{l}\text { (国·自 } \\
\text { 治体) } \\
\text { 社会的 } \\
\text { 復興 } \\
\text { 不卜 } \\
\text { 減少 }\end{array}$ & + & 0 & 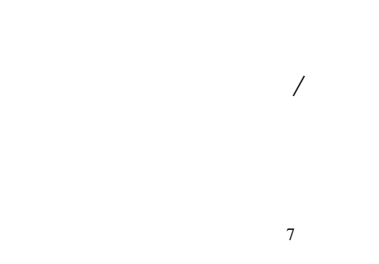 \\
\hline $\begin{array}{l}\text { (買主) } \\
\text { 耐 震 強 } \\
\text { 度 の高 } \\
\text { い物 件 } \\
\text { に対す } \\
\text { る峻別 }\end{array}$ & $\begin{array}{l}\text { ( 中古 } \\
\text { 住宅市 } \\
\text { 場) 物価 } \\
\text { の耐震 } \\
\text { 強度に } \\
\text { よる価 } \\
\text { 格形成 }\end{array}$ & + & O & 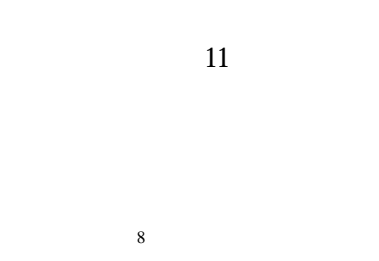 \\
\hline
\end{tabular}

※因果関係は, + : 正の因果関係, 一 : 負の因果関係, $\square$ : 因果関係不明, $\times:$ 因 果関係なし

※根拠強度は, ○: 信頼できる根拠あり， $\triangle:$ 弱 根拠あり，×：根拠なし 
しかし, 本研究て取り上げた社会問題解決策は, いず れも既存の制度にない新たな制度であり，既存資料のみ では将来を予測するための根拠データは十分でなかった 特に，本制度の影響分析の上でポイントとなる耐震診 断・耐震改修の意思決定に関するデータや, 耐震性住宅 の価格差への許容度に関するデータといった個人の意思 決定に関する情報はあまり見られなかった .

(2) インターネットアンケートによる因果関係の検討 耐震改修・耐震診断に関する個人の意思決定や耐震性 住宅の価格と選好に関するデータを得るためのアンケー 卜調査を実施した。

a. アンケートの概要

調査は (株) 三菱総合研究所 eResearch を活用したイ ンターネットアンケートとして実施した .

調査対象は持ち家または賃貸の一戶建てに住む 20 歳 以上の男女とした.平成 15 年 2 月 21 日〜2月 24 日の期 間に実施し，有効回答 1,100 件を得た 。

b. 現状認識レベル (リスク認知) に関する分析

以下ては, 住宅の築年数が 21 年以上 (1982 年 2 月以 前に建てられたもの. 概ね旧耐震基準時代に建てられた 建築物とみなすことができる .)の回答 334 件について集 計を行った。

10 年以内の大地震の発生リスクについては,「きっと 起こる」(13.5\%)，「たぶん起こる」(34.1\%) を合わせて 約 5 割刅大地震発生のリスクを認知, 大地震の際の住宅 への被害のリスクについては、「倒壊の危険」を認識して いる割合は $36.5 \%$ ，「倒壤しないが被害が大きい」が $38.9 \%$ ，「多少の被害」が $20.4 \%$ で, 9 割以上の人が何ら かの住宅への被害を予想していた .

耐震晾断について「せひ受けてみたい」(3.0\%)，「受 けてみたい」(19.8\%) を合わせて約2 割力利用意向を持 ち，耐震改修について「せさ受けてみたい」(0.9\%)，「受 けてみたい」(10.5\%) を合わせて約 1 割力浰用意向を持 っていた

耐震晾断，耐震改修を「あまり受けたくない」受ける つもりはないっと回答した人に关の理由を聞いたところ，

「費用かかかるから」か㵊も多く (耐震診断で $38.3 \%$ ， 耐震改修で $51.2 \%)$ ，产の他として「耐震診断をするまで もなく自分の家は安全でいと思うから」大地震による 被害は避けられないと思うから」「効果がよく分からな い」適正な業者がわからないから」面倒だから」など カ挙げられた .

\section{c. コストレベル (コスト合理性判断) に関する分析}

以下では, 住宅の築年数に関わらず全ての有効回答 1,100 件について集計を行った .

(1)中古住宅耐震性価格査定制度導入の仮想的状況下にお

\section{けるコスト合理性判断}

中古住宅耐震性価格査定制度力導入されたという仮定 のもと, 中古住宅を購入することを想定して, 耐震強度 の高い住宅と低い住宅の価格差に応じた，買い手側の高 耐震性住宅への選好を把握した .

耐震強度の高い住宅と低い住宅の価格差が 50 万円で ある場合には9割以上か洏震性の高い住宅を選ぶとし， 価格が大きくなるほど選好度は低下したが, 価格差が 200万円でも約4割は耐震性の高い准宅を選好していた . $50 \%$ \%力耐震性の高い住宅を選好する価格差は約 148 万円であった .

$\begin{array}{lllllllllll}0.0 & 10.0 & 20.0 & 30.0 & 40.0 & 50.0 & 60.0 & 70.0 & 80.0 & 90.0 & 100.0\end{array}$

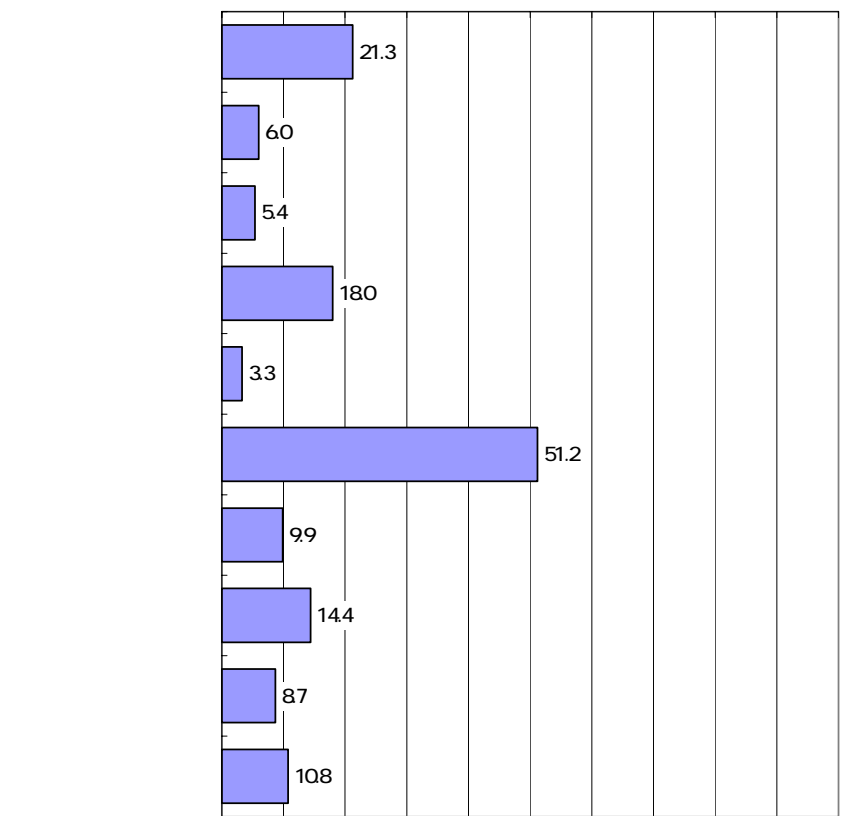

Fig. 7 耐震改修を受けなし 理由 (耐震改修利用意向のない人)

また ，中古住宅を賃貸することを想定し，耐震強度の 高い住宅と低い住宅の家賃月額の価格差に応じた , 借り 手側の高耐震性住宅への選好を把握した .

家賃価格差が 5 千円/月である場合には 4 分の 3 以上 か洏震性の高い住宅を選ぶとしたが , 価格差が大きくな るほど選好度は低下し 2 万円/月からは急速に低下した 。 $50 \%$ の人洏震性の高い准宅を選好する家賃価格差は月 額約 9,200 円であった .

(2)中古住宅売買時耐震性説明責任制度導入の仮想的状况 下におけるコスト合理性判断

中古住宅売買時耐震性説明責任制度力薄入されたこと を想定し，中古住宅売却時の耐震強度の高い住宅と低い 住宅の売却価格の差を変化させて, 住宅所有者 (売り手) としての耐震钐断 耐震改修の利用意向を聞いたところ， 価格差があ (耐震住宅の方か高額で売却できる) 場合 の耐震診断・改修の利用意向力強く，売却時の価格差が ある場合乥の価格差に関わらず (調査における価格差の 最小值は 50 万円)耐震診断利用意向は6割师度であった . 
(3)生命保険料割引制度導入の仮想的状況下におけるコス 卜合理性判断

生命保険料割引制度か薄入されたことを仮定した場合 に，耐震性か高い住宅に住む人の生命保険料の割引率が どの程度であれは耐震診断及ひ耐震改修工事を利用する かについて聞いた . 耐震診断については, 割引率が $1 \%$ の場合には 3 割弱に利用意向が見られたが，二れは，制 度導入を仮定しない場合の耐震㟝断利用意向と同程度で あり，この条件で制度導入による効果はほとんどない ことが示唆された .一方, 割引率か高くなるほと利用意 向は高くなり,割引率が $10 \%$ 場合には半数以上に利用 意向があった .

耐震改修については，割引率が $1 \%$ \%場合には2 割弱 に利用意向が見られた .これは，制度導入を仮定しない 場合の利用意向よりやや高い程度で，この条件での制度 導入による効果はあまり期待できないことが示唆された 。 一方 割引率か高くなるほど利用意向は緩やかに上昇し， 割引率が $10 \%$ の場合には 3 割に利用意向があつた .

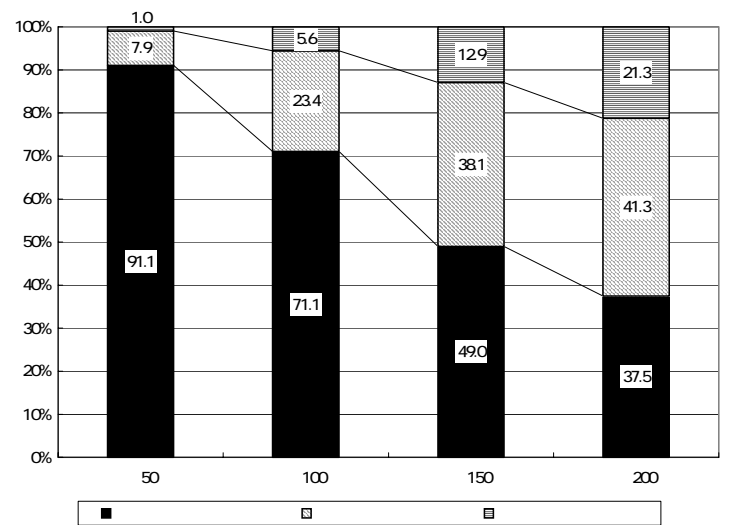

Fig. 8 中古住宅耐震性価格査定制度 (購入時) の耐震性住宅の 選好

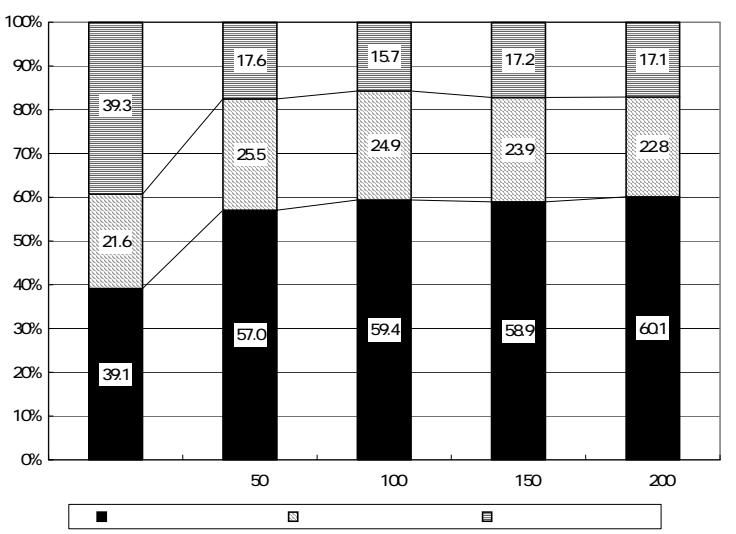

Fig. 9 中古住宅売買時耐震性説明責任制度における耐震診断 の意向

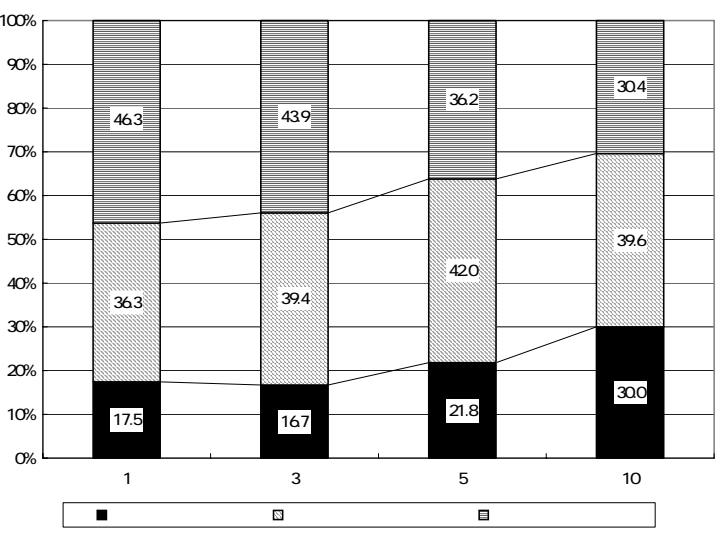

Fig. 10 生命保険料割引制度における耐震改修の意向

\section{c. 検討結果のまとめ}

(1)リスク認知とコスト合理性

地震発生のリスク認知 (約 5 割)，住宅被害のリスク認 知 (9 割) とも比較的高く, 本稿て検討した「個人の意 思決定モデル」における現状認識レベルに起因する要因 は大きくないことがうかがわれた .一方，耐震診断をす るまでもなく自分の家は安全でない」大地震による被害 は避けられない」といったあきらめや「自分の家は安全」 (過度の自信), 「適正な業者がわからない」(必要な情報 の不足)，「面倒だから」といった理由て耐震診断を受け ない人かいることか把握され, モデルに新たな要因を追 加することが必要と考えられた .

また，耐震部断，耐震改修ともに利用しない理由とし て費用を挙げる人が最も多く，コスト合理性及び資金調 達可能性が大きな障害となっていることがうかがわれた .

以上から , 意思決定モデルの基本構造か支持される結 果か得られ，さらに「あきらめ」などの非合理性をモデ ルに導入する必要性が示された .

(2)中古住宅耐震性価格査定制度シナリオ

中古住宅耐震性価格査定制度については, 中古住宅購 入 (買い手側) の場合は 150 万円程度の価格差までであ れば高耐震性住宅が選好され，中古住宅賃貸 (借り手側) の場合は月額 1 万円程度の価格差までであれば高耐震性 住宅が選好された . 耐震性住宅を選好するかどうかは価 格差の程度と関係しており，意思決定モデルのコスト合 理性か実際に機能していることか沶唆され, シナリオ及 び因果ネットワークを支持する根拠力得られた .

(3)中古住宅売買時耐震性説明責任制度シナリオ

中古住宅売買時耐震性説明責任制度については, 売却 価格差によらす耐震言断の意思決定がされていたこと から , コスト合理性判断のレベルというより，売主によ る耐震性についての説明か義務づけられることによる心 理的な圧力か洏震診断を受けるインセンティブとして機 能することが示唆された . 
(4)生命保険料割引制度シナリ才

生命保険料割引制度については, 他の 2 制度と比較し て耐震診断・改修の意思決定に及ぼす効果がささかった . しかし, 耐震部断・耐震改修の意思決定力割引率に影響 されることから，コスト合理性か意思決定に影響を与え る要因であることがうかがわれた . 割引率の設定により 被保険者がどの程度メリットを感じることができるかと いう点か制度の導入にあたって重要になることや, 割引 率を $10 \%$ 程度に設定できれば,中古住宅売買時耐震性説 明責任制度と同程度の効果か期待できることが示唆され た。

(5)制度間の比較・評価

以上の結果から，制度の比較評価を行った。

個人の意思決定行動については, 中古住宅耐震性価格 査定制度が, 物件売買についてコスト合理性を担保でき る (投資資金の回収が見込まれる) ことから，最も有望 であると評価された .一方, 同制度では賃貸の場合はコ スト合理性の担保ができず，制度導入の効果は大きくな いと見込まれた 。

中古住宅売買時耐震性説明責任制度は中古住宅耐震性 価格査定制度に比較して効果力弱いことがうかがわれ， さらに, 生命保険料割引制度では十分な効果が見込める 割引率 (10\%以上) の設定は現実的には制約があるもの と考えられた .

\section{5. シナリオの評価}

住宅メ一カ一の業界団体，住宅業界紙編集長及ひ保険 アクチュアリー (保険料算定の専門家) の3 名へのイン タビューにより, 各々の専門の立場から, シナリオの信 頼性や実現可能性について評価してもらった .

Table. 7 インタビュー対象者

\begin{tabular}{|l|l|}
\hline 評価者 $\mathrm{A}$ & 住宅メーカ一業界団体 \\
\hline 評価者 $\mathrm{B}$ & 住宅業界紙編集長 \\
\hline 評価者 $\mathrm{C}$ & 防災研究者・元損保アクチュアリー \\
\hline
\end{tabular}

\section{(1) 既存住宅の耐震性向上問題を取り巻く状況}

住宅業界ては 既存住宅の耐震性向上への関心か高い． 業界団体力税制に関する要望書をまとめるなと積極的な 取り組みを行っており，住宅流通の活性化のため，従来 の「作っては壊し」のアプローチから , 良質なストック の蓄積への転換を志向することが必要であると言われる

本インタビューでは，国に中古住宅流通を管轄する特 定の部門かなく，中古住宅問題に関する政策か不足して いるとの指摘や，不動産仲介業界で耐震性評価に関す る取り組みが十分でないとの指摘か得られた . また，耐 震性住宅の価值や耐震性向上の意思決定に関する実証的 データは十分でなく, 本研究の取り組みは重要であると
の意見も見られた .

3 者とも, 米国では住宅の品質や安全性確保に関して 日本に比較して多樣な政策オプションか採られており参 考にすべきとの意見で一致していた .

\section{(2) 中古住宅耐震性価格査定制度}

中古住宅耐震性価格査定制度の導入シナリオに対して は、最近販売された免震住宅への関心か高いなど消費者 の潜在的二ーズは高く, 本制度も市場への大きな効果が あるはず」(評価者 A)，「米国では住宅売買の際に，專門 家による検査・評価か行われている(インスペクター制 度). 日本にも同樣の仕組みが必要」(評価者 B)，「耐震 性を含めた性能表示を推進することで質の高い住宅の選 別につながる」(評価者 C) との期待感力表明される一方 で、「中には悪質な業者もおり，業者に関する情報提供な ども必要」「中古住宅流通は年間 30 40 万戶程度と少な く本制度が全国の新耐震基準を満たしていない住宅(約 1300 万戶) の建替えを促進するに足るインセンティブと なるには中古住宅市場の拡大力前提」(評価者B) との効 果の限界や，耐震部断の方法や基準は統一されておらず 全国的な制度構築の際の障害となりうる」(評価者 C) と の実現に向けた課題を指摘する意見が見られた「本制度 のみではなく税制など複合的なアプローチが必要」(評価 者C) との指摘で3 者は一致していた .

\section{(3) 中古住宅売買時耐震性説明責任制度}

中古住宅売買時耐震性説明責任制度の導入シナリオに 対しては, 中古住宅耐震性価格査定制度に比較してやや 高し 評価力得られ，「現在は，耐震性に関する情報はほと んどないが,情報があれば消費者の意識は変わる」(評価 者A）「情報の非対称性をなくすことか洧効」(評価者B)， 「中古住宅保証制度の普及はいまだ十分とは言えず，保 証制度の後押しのためにも本制度は有効である」(評価者 A，B），「性能表示の推進は保険制度よりも有効に機能す るのではないか」(評価者 $\mathrm{C}$ ) と情報提供を重要視する見 方が3者から示された .

弚の一方で古住宅耐震性価格査定制度と同樣に複合 的なアプローチが必要である点力課題として指摘された .

\section{(4) 生命/損害保険料割引制度}

生命/損害保険料割引制度の導入シナリオに対しては， 評価は概ね低いものであった（以下の評価はいずれも評 価者 Cによる) .

まず，生保，損保とも住宅の耐震性に基づく保険料の 割引を行うインセンティブは高くないことか問題として 指摘された . 損保の傷害保険は通常集団で加入すること が多いため, 個別のリスクを評価することにはなじまず， 生保ではがんなどの疾病リスクの方か要因として大きく， 
自然災害要因を個別に評価することのインセンティブが 小さい (一部の傷害保険 (集団加入でないもの) では住 宅の耐震性などを考慮した商品力検討されている) .

また地震保険の場合，質の高い准宅の保険料を割り引 くことて保険会社として抱えるリスクを低減させるメリ ットがある反面，(1)耐震診断の方法や水準力統一されて おらず, 行政側も全国的な制度の確立力困難 , (2)耐震性 証明に関する手続きか煩雑であることも制度の障害にな りうる，(3)既存不適格住宅の居住者は高齢者であること が多く資金調達やリスク認知に課題があるといった課題 があることか指摘された 、これらを踏まえ，実現に向け て複合的なアプローチが必要であるとの指摘かなされた .

\section{(5) 制度間の比較・評価}

以上の結果から，制度の比較評価を行った。

専門家の評価では，中古住宅売買時耐震性説明責任制 度が最も有望で, 情報提供による消費者側の意識変化を 期待する声が多かった .一方, アンケート結果から最も 効果的と評価された中古住宅耐震性価格査定制度は, 制 度を促進するための環境的な要因面での制約が大きく， 専門家からの評価は中程度であつた . 生命/損害保険料 割引制度については, 当初予想した以上に制度的な制約 が大きく，実現は困難と判断された．

専門家による評価を通じて, 当初想定されていなかっ た問題の広がりか認識され、また業界と国との価値観の 相違、業界内での立場の相違があることが把握された。

\section{4. 考察}

\section{1. 本手法の特徵と有効性}

本研究では, 影響分析手法に基ついて, 既存不適格住 宅の耐震性向上問題に関する解決方策について既存文献 の収集・分析やアンケート調査, インタビュ一調査など により，既存不適格問題解決のための制度導入のシナリ オ (因果ネットワーク) の作成・検討・評価を行った .

既存文献調査ては，シナリオの一部を裏付ける資料が 得られた . しかし, 新たな制度の導入効果という将来の 事象に関する根拠の判定を，既存の情報からだけで行う のは不十分であり，案件ごとに独自の情報収集が必要で ある.これら不足する情報を補う目的でアンケート調査 を実施し，限定された情報ではあるが，耐震改修等に関 する個人の意思決定の構造と影響要因およひ仮想的状況 下における行動に関するデータを得ることができた .

さらに, 各分野の専門家からの評価を通じて, シナリ 才実現に向けた課題や実現に向けてのボトルネックに関 する示唆を得ることができ, また, 複数の解決策の評価 につながる可能性も示唆された . 評価結果からは当初の シナリオに含まれていなかった問題の広がりや, 関連す るステークホルダーの立場による価值対立か存在するこ
とがうかがわれた .

以上のように, 社会問題解決策の影響分析手法を既存 不適格住宅耐震性向上問題に適用したところ，制度導入 に伴う影響について分析を行い一定の成果を得ることが できた .このことから本手法の有効性が示唆されたもの と考えられる . また , 本手法を他の社会問題に適用する ことの有効性と課題についても示唆を得ることができた . 本手法は，従来専門家が個別領域で行ってきた社会シ ステムにとっての要素間の因果関係に関する検討を, 社 会システム全体を包括的に鳥瞰する全体像に位置つけする ことを可能とする.このため，本手法を用いることで， 従来分析対象分野の限られた専門家か発見的・非明示的 に行ってきた影響分析のプロセスか明示化され，結果を 客観的に検証することか容易になるものと考えられる .

また，個別領域の専門性を越えて共通の問題意識や視 点を共有し議論することが可能になる.実際, 本研究に おいても，作成したシナリオを共通の土俵としたことで， 異なる分野の専門家と意見交換することか容易になった . 専門分化により科学技術を社会へ適用する障害となって いると指摘される現状の改善に役立つものと期待される .

\section{2. 今後の課題}

本研究て例示されたように, 因果ネットワークは, 新 たな問題解決策 (制度) を分析の対象としていることか ら，一般には既存の情報からだけて根拠の評価・検証を 行うことは不十分で, 対象とする解決策ごとに独自の情 報收集・分析が必要となろう. 根拠の検証のために用い る手法としては, 一般の人を対象とした CVM あるいは それに類似したアンケート調査や, 専門家へのヒアリン グ (デルファイ法のような手法を含む) などがありえる が, 本手法によりよく適合するような精緻化が必要であ ろう. 具体的には , 仮想的状況下での意思決定に関する 調査手法としての有効性やデータの信頼性の検証や，七 アリングで得られた意見の数量化などの課題が考えられ る.また，今回の検討を通じて得られた「意思決定モデ ル」のような因果ネットワークに用いるテンプレートを 整備していくことも有効であろう.

本研究ではインタビューを通じたシナリオへの評価や， 複数のシナリオがある場合の比較などについて, 一定程 度の成果力得られたものの, シナリオの評価についての 方法論や, 複数の解決策がある場合の選択に関する考え 方は十分整備・体系化されておらず，今後検討すべき課 題である .

また , インタビューからは立場による価値対立の構造 がうかがわれたが，この点に関するアプローチは十分で はない . 今後, 対立する価值の明示化およひ対立構造の 分析方法, 対立の解消のあり方などに関する方法論の開 発が必要である。 


\section{5. まとめ}

本研究ては問題解決策の影響分析手法に実際のケースを 適用する試みを通じて, 本手法の有用性と課題について 検討した . 具体的には，既存不適格住宅の耐震性向上の ための新制度について影響分析を行い, 各制度導入時の 影響に関する示唆を得ることができた . また，限定され た情報からではあるが, 制度の有効性と限界について具 体的に把握し, 各制度導入に際しての留意すべき点を抽 出し整理した。

本手法の特徵として次のような点を挙げることができ る . (1)社会システム全体を取り込んだ包括的な予測手法 であり, さらにシステムの要素間のミクロの因果関係も 明示することかできる . (2)専門家か発見的・非明示的に 行ってきた予測のプロセスを明示化して示すことができ， 専門家, 非専門家を問わず予測の信頼性, 妥当性につい て広く議論あるいは評価することか可能となる．

今後は, 具体的なケーススタディを通じて , 社会技術 の評価・選択の方法論, 対立する価值構造へのアプロー チの方法につて検討することが必要である.

\section{参考文献}

1）堀井秀之(2004)『問題解決のための「社会技術」』中央公 論新社

2) Dunn, W. N. (1981), Public Policy Analysis: An Introduction, Prentice-Hall
3）宮川公男(1994）『政策科学の基礎』東洋経済新報社

4) 印南一路(1997)『すぐれた意思決定』中央公論新社

5) 小松崎俊作, 橋口猛志, 堀井秀之(2003)「因果ネットワー クを用いたリアルタイム診療ナビゲーションシステムの 影響分析」『社会技術研究論文集』1，391-403

6) 村山 明生, 古場 裕司, 舟木 貴久, 城山 英明, 畑 中 綾子, 阿部 雅人, 堀井 秀之(2003)「既存不適格住 宅の耐震性向上に係る社会技術の研究」, 『社会技術研究』 $1,338-351$

7)国土交通省住宅局(2001)『中学生のための住まいの安全チ ェック (耐震改修推進調査の結果)』, http://www2.bcj.or.jp hmm/earthquake/result.htm [2004.June.11]

8) 山鹿 久木, 中川 雅之, 齊藤 誠(2002)「地震危険度と 家顀: 耐震対策のためめ政策的インプリケーション」,『日 本経济研究』第 46 号

\section{謝辞}

本研究において, 有益な助言をいただいた (株) 三菱 総合研究所村山明生氏, 舟木貴久氏に感謝の意を表しま す.なお本研究は, 社会技術研究システムミッション・ プログラム「安全性に係わる社会問題解決のための知識 体系の構筑」(平成 13〜14 年度は日本原子力研究所の事 業, 平成 15 年度からは科学技術振興事業団の事業) の成 果の一部である .

A Study towards establishing influence-analysis method for measures against social problems - A case study on social problem of improving earthquake-resistance of existing pre-code-revision houses

$$
\text { Yuji Koba }{ }^{1} \text {, Satoshi Shirato }{ }^{2} \text {, Kentarou Yamaguchi }{ }^{3} \text {, and Hideyuki Horii }{ }^{4}
$$

${ }^{1}$ M.S. (Multidisciplinary Sciences) Mitsubishi Research Institute, INC., Social-System Policy Dept. (E-mail:y-koba@mri.co.jp)

${ }^{2}$ M.E. (Mechanical Engineering/Science Policy) Mitsubishi Research Institute, INC., Dept. of Social Infrastracture System (E-mail:s-shirato@mri.co.jp)

${ }^{3}$ M.E. (Social-System Policy) Mitsubishi Research Institute, INC., Dept. of Social Infrastracture System (E-mail:yamaken@mri.co.jp)

${ }^{4} \mathrm{Ph} . D$. (Science and Technology for Society), The University of Tokyo, Department of Civil Engineering (E-mail: horii@ civil.t.u-tokyo.ac.jp)

It is important to analyze influences of a measure against social problems. It will enable the clarification of tasks at the implementation of the measure and its pre-evaluation. In this study, a method of influence analysis for measures against social problems is applied to an existing social problem. As an example of measures against social problems, effects of new institutions to improve earthquake-resistance of substandard houses are analyzed through influence-analysis method. Their effect and limitation are presented and the applicability of the method is discussed.

Key Words: measure against social problems, influence analysis method, complex problem solving, decision making, pre-code-revision houses 